\title{
OBITUARY
}

\section{Jacqueline Viaux (1914-1998)}

It seems unbelievable that someone as dynamic as Jacqueline Viaux should no longer be among us.

With her death we have lost a good friend, one who was known to many ARLIS members as well as to art librarians involved in international cooperation. We have much cause to be grateful to her.

At the 1976 international ARLIS conference in Brighton, it was generally thought that international co-operation between art librarians and art libraries was essential - but the form that this should take was not unanimously agreed. A voice coming out strongly in favour of working under the umbrella of IFLA was Jacqueline's. Tentative approaches were made and soon a Round Table of Art Libraries was set up within IFLA and under the chairmanship of Jacqueline. First Judy Hoffberg of the USA, then Noelle Balke of Canada, served as secretaries to the Round Table. Then in 1979 it was my turn. I had two years of working with this amazing woman. At the time she was Conservateur-en-chef of the Bibliothèque Forney. She did not conform to the general idea of the typical Parisienne: she did not pretend to be unable to understand you if you spoke to her in execrable French, she was not particularly interested in food, and she certainly did not care about clothes!

I soon learnt that when Jacqueline was working, she was totally focused and nothing got in the way. I think she alarmed some people by her fierce dedication, her outspokenness, her lack of small talk and her occasionally brusque manner. She described herself as "an old bear". She was kindness itself and you always knew where you were with her - there was no hypocrisy, no beating about the bush.

She was devoted to her large family (five children and numerous grandchildren) as well as the family house at Veyrier-du-Lac on Lake Annecy, where she and her husband grew vast quantities of fruit which needed processing. To go there she went by car, but to move about in Paris she used her moped - right to the end: a terrifying sight! If she wanted to show me places in Paris that I had never visited, we used public transport, and I can remember a magical winter picnic in the gardens of the Bagatelle - about which, of course, she was knowledgeable and instructive, but where she also recited a large chunk of Squirrel Nutkin at me.
Jacqueline was ideal as the first chair of the Round Table. Unlike the rest of us, she was familiar with IFLA bureaucracy, knew many of the leading personalities and was no shrinking violet when it came to getting what she wanted.

The early IFLA days were not easy. We were very thin on the ground; apart from ARLIS and ARLIS/NA delegates there were only two from France and one from Germany, as well as several from Canada. Scandinavia soon participated, but no other countries had art library associations in those days and the first priority was to find out who was out there and to let them know about us. It was decided that a directory of art libraries was needed. Jacqueline was determined to produce this, although with no computer and few contacts, what we compiled was not wonderful. But it was a start.

We did have the resources of the Bibliothèque Forney to help us. Jacqueline was rightly proud of "her" library. When, at her retirement, she was honoured by the city of Paris with the grande médaille d'or de la Ville de Paris she pretended to mock, but she was pleased.

After her retirement she was made Conservateur honoraire of the Forney. She was now free to do what she had always done: to travel. My, how she travelled! Neither age nor discomfort deterred her. After a great deal of homework, she would set out for Laos, South America, China, the Yemen postcards would arrive from all over the world accompanied by a variety of scraps of paper, for no postcard was big enough to contain it all. And she attended innumerable art library conferences, including most recently those in Barcelona, Istanbul, Montreal, Paris, San Antonio, Texas and Trieste.

After her retirement she also had more time to write and to compile her furniture bibliography. She remained involved with the work of international art librarianship. She remained passionate about everything she undertook. She was indefatigable. She was unique.

Vera Kaden 